\title{
Research on the Influence of Regional Marketization Degree on the Effect That Internal Control Suppresses Enterprises to Make Quick Money
}

\author{
Yuni Wu \\ School of Business Administration, South China University of Technology, Guangzhou, China \\ Email: 383472987@qq.com
}

How to cite this paper: $\mathrm{Wu}, \mathrm{Y} . \mathrm{N}$. (2018) Research on the Influence of Regional Marketization Degree on the Effect That Internal Control Suppresses Enterprises to Make Quick Money. American Journal of Industrial and Business Management, $\mathbf{8}$, 2334-2343.

https://doi.org/10.4236/ajibm.2018.812156

Received: November 19, 2018

Accepted: December 16, 2018

Published: December 19, 2018

Copyright $\odot 2018$ by author and Scientific Research Publishing Inc. This work is licensed under the Creative Commons Attribution International License (CC BY 4.0).

http://creativecommons.org/licenses/by/4.0/

\begin{abstract}
This paper takes the 2007-2016 Shanghai-Shenzhen A-share main board listed company as a sample to empirically examine the effect of the degree of marketization in different regions on the influence of high internal control quality of listed companies' suppression on making quick money. It is found that the suppression of the quality of internal control of enterprises is only reflected in the enterprises in high-market areas. Furthermore, the higher the degree of marketization is, the more obviously internal control suppresses making quick money.
\end{abstract}

\section{Keywords}

Internal Control Quality, Regional Marketization Degree, Make Quick Money

\section{Introduction}

There is a contradiction between the real estate industry's investment in real estate and the financial industry to "make quick money" and the urgent need for transformation of the real economy. How to restrain enterprises from "making quick money" has become a problem worthy of attention. Studies have shown that high-quality internal control can restrain enterprises from making quick money. However, China's A-share listed companies are distributed in various regions. Will the degree of marketization in different regions affect the relationship between internal control quality and making quick money? In order to solve this problem, this paper uses the data of the Shanghai-Shenzhen A-share 
main board listed company from 2007 to 2016 to empirically examine the influence of the degree of marketization in different regions on the effect of high internal control quality of listed companies' suppression on making quick money.

The rest of the paper is organized as follows: the second part is the literature review; the third part is the theoretical analysis and research hypothesis; the fourth part is the research design; the fifth part is the empirical test and the result analysis; the sixth part is the further analysis; the last is the conclusion.

\section{Literature Review}

The rapid profit of enterprises refers to their short-term arbitrage in the financial and real estate industries. It also refers to entrepreneurs who make government officials and foreign investment immigrants [1] [2] [3]. This article focuses on the former. The profit from making quick money has not been used to feed back the main business, but has reduced the level of innovation in the main business [3], which is not conducive to the transformation and upgrading of China's real economy. Existing research has proven that high quality internal controls can inhibit companies from making quick money, but will there be a difference in the impact of companies in different regions? This is also a question worthy of study, which will help to develop a differentiated system for different regions.

Fan Gang and Wang Xiaolu [4] [5] have long been committed to quantifying the degree of marketization in various regions of China. The research on the marketization index of various regions from 2007 to 2014 has also become a basis for a large number of regional marketization studies. Some studies target macroeconomics. For example, Li Shuangyan and Miao Jin (2018) studied the impact of marketization as a mediator on the relationship between corruption and capacity utilization [6]. Some studies focus on sociological issues. For example, Zhang Xiaoyun (2018) studied the role of regional marketization in eliminating discrimination in height [7]. More research is to explore the impact of regional marketization on companies. For example, Wang Zhenshan and Wang Hao (2018) studied the relationship between equity checks and balances, marketization and corporate debt maturity [8]. However, there has not been any research on the impact of regional marketization systems on the quality of internal control and the relationship between making quick money.

\section{Theoretical Analysis and Research Hypothesis}

The operation of the company will be affected by the market environment in its region. Chinese scholars Fan Gang and Wang Xiaolu have long been committed to quantifying the degree of marketization in the region. They divide the market-oriented total index, which measures the degree of marketization in the region, into five indicators, namely, "the relationship between the government and the market" and "the development of non-state-owned economy, the degree of development of the product market, the degree of development of the factor market, 
the development of market intermediaries and the legal environment of the market. Among the five indicators, the "government-market relationship" measures the degree of government participation, "the development of non-state-owned economy", "the degree of development of product markets" and "the degree of development of factor markets" measure the degree of market competition. "The development of market intermediaries and the legal environment of the market" measure the degree of rule of law. Therefore, this paper will analyze the impact of regional marketization on the relationship between internal control quality and making quick money from three aspects: government participation level, market competition degree and legalization degree.

The high level of government involvement means that the government has a greater intervention in the Enterprise. Corporate performance affects local GDP and fiscal revenue, while local GDP and fiscal revenue are linked to the promotion of local government officials [9]. Therefore, when the degree of government participation is high, the investment decision-making process of Enterprises will be greatly affected by the government [9]. Even if the internal control quality of the Enterprise is high, it may only be in the form. Under the intervention of the government, it has to make quick money, improve the performance of the Enterprise by "making quick money", and "seek welfare" for the local government.

Low market competition means that the market's price mechanism is not mature, local protectionism is strong, regional finance is backward, and manpower supply is insufficient. The low degree of rule of law means that the maturity of law firms, accounting firms and other intermediaries is low, and administrative law enforcement intensity is low too. When the degree of market competition and the degree of rule of law are low, it may cause Enterprises to be free to compete in the region, and information on the external business environment is difficult to obtain [10], financing constraints are large, and property rights are protected to a lesser extent. And the difficulty of safeguarding rights, etc., all of which will lead to the difficulty in realizing the company's strategy and business objectives, and thus affect the business performance of the company. Once the company's business objectives are difficult to complete, even if its internal control quality is high, it may have to make quick money to make up for the damage caused by the poor market environment.

Based on the above analysis, this paper proposes that under the same conditions, the market environment in the region where the Enterprise is located will affect the relationship between internal control quality and making quick money. When the degree of marketization is low, there is no significant correlation between internal control quality and making quick money. When the degree of marketization is high, there is a significant negative correlation between internal control quality and making quick money, and the higher the degree of marketization, the greater the inhibition of high internal control on making quick money.

\section{Research Design}

The definition of each variable in this paper is shown in Table 1. 
1) Internal control quality. This paper draws on the research of Fang Hongxing and Jin Yuna (2013), which is measured by "whether a listed company has one of the conditions for characterizing low-quality internal control (is 0 , no 1) [11]. The specific measurement method is shown in Table 2.

2) The degree of regional marketization. This paper uses the market-oriented total index of China's sub-provins issued by Fan Gang and Wang Xiaolu (2011, 2017) to measure the degree of regional marketization [4] [5]. Since the marketization index released by Fan Gang and Wang Xiaolu $(2011,2017)$ was only updated to 2014, this paper draws on the research of Lin Chuan (2015) and uses the marketization index of each region in 2014 to measure the degree of marketization in 2015 and 2016 [12].

This paper constructs the following regression model to test the hypothesis. In the formula, $i$ represents the Enterprise, and t represents the year. The definition of each variable is shown in Table 1.

$$
\begin{aligned}
\mathrm{MQM}_{\mathrm{it}}= & \beta_{0}+\beta_{1} \mathrm{ICQ}_{\mathrm{it}}+\beta_{2} \mathrm{RMI}_{\mathrm{it}}+\beta_{3} \mathrm{ICQ}_{\mathrm{it}} \times \mathrm{RMI}_{\mathrm{it}}+\beta_{4} \text { State }_{\mathrm{it}}+\beta_{5} \text { Lnasset }_{\mathrm{it}} \\
& +\beta_{6} \mathrm{Roe}_{\mathrm{it}}+\beta_{7} \text { Leverage }_{\mathrm{it}}+\beta_{8} \text { Revgrowth }_{\mathrm{it}}+\text { Year }+ \text { Industry }+\varepsilon
\end{aligned}
$$

We expect that in the regression results, the ICQ coefficient will not be significantly negative, should be not significantly negative or not significant, and the ICQ $\times$ RMI coefficient is significantly negative.

\section{Empirical Test and Result Analysis}

\subsection{Descriptive Statistics}

The descriptive statistics of the main variables of the full sample and the grouped samples are shown in Table 3.

In terms of internal control quality, the average internal control quality (ICQ) is 0.7860 , indicating that the number of companies with high quality internal control accounts for $78.60 \%$, and the quality of internal control of most listed companies is high.

In terms of making quick money, the average value of MQM is 0.0141 , indicating that the average financial and real estate industry income of each listed company accounted for $1.41 \%$ of total operating income, which is similar to the descriptive statistics of Wang Hongjian et al. (2016) [3].

In terms of regional marketization, the average marketization index (RMI) of the region where the enterprise is located is 7.4266 . The national average marketization index in 2014 is 6.56, which is lower than the average of the sample, indicating that the majority of listed companies are highly marketized in Eastern and central regions.

\subsection{Correlation Analysis}

The correlation coefficients of the main variables are shown in Table 4. The correlation coefficient between the explanatory variable and the control variable is less than 0.5 , indicating that the degree of multicollinearity between the explanatory variable and the control variable is weak. 
Table 1. Variable definition table.

\begin{tabular}{|c|c|c|c|}
\hline Type & Name & Symbol & Variable definition \\
\hline $\begin{array}{l}\text { Explained } \\
\text { variable }\end{array}$ & $\begin{array}{l}\text { Make quick } \\
\text { money }\end{array}$ & MQM & $\begin{array}{l}\text { Revenue share of financial and real } \\
\text { estate industry in operating income }\end{array}$ \\
\hline \multirow{3}{*}{$\begin{array}{l}\text { Explanatory } \\
\text { variables }\end{array}$} & $\begin{array}{l}\text { Internal control } \\
\text { quality }\end{array}$ & ICQ & $\begin{array}{l}\text { The internal control quality is } 1 \\
\text { for high quality and } 0 \text { for low quality }\end{array}$ \\
\hline & $\begin{array}{c}\text { Regional } \\
\text { marketization }\end{array}$ & RMI & $\begin{array}{l}\text { The total marketization index corresponding } \\
\text { to the province where the Enterprise is located } \\
\text { (published by Fan Gang and Wang Xiaolu, etc.) }\end{array}$ \\
\hline & $\begin{array}{l}\text { Nature of } \\
\text { property }\end{array}$ & State & $\begin{array}{l}\text { If the Enterprise is a state-owned holding } \\
\text { company, it is } 1 \text {, otherwise it is } 0\end{array}$ \\
\hline \multirow{6}{*}{$\begin{array}{l}\text { Control } \\
\text { variable }\end{array}$} & Business scale & Lnasset & $\begin{array}{l}\text { Natural logarithm of total assets } \\
\text { at the end of the period }\end{array}$ \\
\hline & Profitability & Roe & $\begin{array}{l}\text { Return on net assets, i.e., } \\
\text { net profit/average total assets }\end{array}$ \\
\hline & Capital structure & Leverage & Asset-liability ratio, i.e., total liabilities/total assets \\
\hline & Growth & Revgrowth & $\begin{array}{l}\text { Operating income growth rate, that is, } \\
\text { (current operating income-previous operating } \\
\text { income)/previous operating income }\end{array}$ \\
\hline & Year & Year & dummy variable \\
\hline & Industry & Industry & dummy variable \\
\hline
\end{tabular}

Table 2. Measurement of internal control quality.

\begin{tabular}{|c|c|c|}
\hline Classification & $\begin{array}{c}\text { ICQ } \\
\text { Assignment }\end{array}$ & Judging criteria \\
\hline Low quality & 0 & $\begin{array}{l}\text { If it has one of the following circumstances: financial } \\
\text { restatement in the current year, irregularity occurred in the } \\
\text { current year, loss in the current year, internal control audit } \\
\text { report issued this year with non-standard opinions, and financial } \\
\text { report audit report issued this year with non-standard opinions. }\end{array}$ \\
\hline High quality & 1 & There are no situations listed in low quality internal controls. \\
\hline
\end{tabular}

Table 3. Descriptive statistics of the main variables.

\begin{tabular}{cccccc}
\hline & Mean & $\begin{array}{c}\text { Median } \\
\text { Standard }\end{array}$ & Deviation & $\begin{array}{c}\text { Maximum } \\
\text { Value }\end{array}$ & $\begin{array}{c}\text { Minimum } \\
\text { Value }\end{array}$ \\
MQM & 0.0141 & 0.0000 & 0.0673 & 0.4964 & 0.0000 \\
ICQ & 0.7860 & 1.0000 & 0.4102 & 1.0000 & 0.0000 \\
RMI & 7.4266 & 7.5500 & 1.8571 & 11.7100 & -0.3000 \\
State & 0.4379 & 0.0000 & 0.4961 & 1.0000 & 0.0000 \\
Lnasset & 21.8947 & 21.7700 & 1.1614 & 25.2200 & 19.5000 \\
Roe & 0.0759 & 0.0800 & 0.1268 & 0.4200 & -0.5800 \\
Leverage & 0.4545 & 0.4564 & 0.2066 & 0.9043 & 0.0517 \\
Revgrowth & 0.1361 & 0.1014 & 0.2964 & 1.5083 & -0.4952 \\
\hline
\end{tabular}


Table 4. Correlation matrix of main variables.

\begin{tabular}{|c|c|c|c|c|c|c|c|c|}
\hline & MQM & ICQ & RMI & State & Lnasset & Roe & Leverage & Revgrowth \\
\hline MQM & 1.000 & & & & & & & \\
\hline ICQ & $-0.026^{* * *}$ & 1.000 & & & & & & \\
\hline RMI & 0.011 & $0.112^{* * *}$ & 1.000 & & & & & \\
\hline State & $-0.017^{\star}$ & $-0.071^{\star * *}$ & $-0.172^{\star * *}$ & 1.000 & & & & \\
\hline Lnasset & $-0.025^{\star * *}$ & $0.023^{\star * *}$ & 0.002 & $0.315^{\star * *}$ & 1.000 & & & \\
\hline Roe & $0.036^{\star * *}$ & $0.403^{* * *}$ & $0.074^{* * *}$ & $-0.050^{\star * *}$ & $0.090^{* * *}$ & 1.000 & & \\
\hline Leverage & $0.103^{\star * *}$ & $-0.220^{\star * *}$ & $-0.110^{\star * *}$ & $0.251^{\star * *}$ & $0.389^{* * *}$ & $-0.196^{* * *}$ & 1.000 & \\
\hline Revgrowth & $0.052^{* * *}$ & $0.130^{* * *}$ & -0.004 & $-0.069^{* * *}$ & $0.016^{*}$ & $0.283^{* * *}$ & $0.016^{*}$ & 1.000 \\
\hline
\end{tabular}

\subsection{Multiple Regression Analysis}

The test results of the degree of regional marketization on the relationship between internal control quality and quick money relationship are shown in Table 5.

The coefficient of internal control quality (ICQ) is not significant, indicating that internal control cannot suppress the rapid money when the degree of marketization is low. The coefficient of ICQ is positive, indicating that internal control is not good when the degree of marketization is low. It is a restraining effect on making quick money, but it makes it easier. The intersection of the internal control quality and the degree of marketization (ICQ $\times$ RMI) coefficients are significantly negative $\left(-0.002^{* *}\right)$ at the $5 \%$ significance level, which is opposite and significant to the ICQ coefficient, indicating when the degree of marketization is high, the higher the degree of marketization, the more the internal control can suppress the quick money. Therefore, the assumption is verified.

\section{Further Analysis}

In the paper, when the hypothesis is put forward, the five aspects of the index under the marketization index are classified into three categories according to the content they reflect. The paper analyzes how the degree of marketization of these three aspects affects on the relationship between quality of internal control and making quick money. Since the paper uses the market-oriented total index when testing the hypothesis, whether the degree of marketization in five aspects will affect this relationship is still unknown.

Therefore, this paper further uses the five aspects of the marketization index to measure the degree of marketization separately, to explore the impact of different aspects of the market environment on the quality of internal control and the relationship between making money. The specific approach is: first, the relationship between government and the market (GI), the development of non-state-owned economy (NEDI), the degree of development of the product market (PMI), and the degree of development of the factor market (EMI) are 
substituted into the RMI variables in the model, and then the samples are returned.

The results of the regression are shown in Table 6. The results after regression with GI, NEDI and PMI are consistent, the internal control quality (ICQ) coefficients are significantly positive, and the interpolated terms (ICQ $\times$ RMI) coefficients of internal control quality and marketization are significantly negative; EMI results In the ICQ coefficient, the ICQ coefficient is not significantly negative, and the ICQ coefficient is not significantly negative, and the ICQ $\times$ RMI coefficient is significantly negative. These results indicate that:

Table 5. Test results of the influence of regional marketization degree on the relationship between internal control quality and quick money.

\begin{tabular}{|c|c|}
\hline Constant & $\begin{array}{l}0.101^{* * *} \\
(0.000)\end{array}$ \\
\hline ICQ & $\begin{array}{c}0.008 \\
(0.141)\end{array}$ \\
\hline RMI & $\begin{array}{c}0.002^{* * *} \\
(0.001)\end{array}$ \\
\hline $\mathrm{ICQ} \times \mathrm{RMI}$ & $\begin{array}{c}-0.002^{* *} \\
(0.012)\end{array}$ \\
\hline State & $\begin{array}{c}-0.005^{* * *} \\
(0.000)\end{array}$ \\
\hline Lnasset & $\begin{array}{c}-0.005^{\star * *} \\
(0.000)\end{array}$ \\
\hline Roe & $\begin{array}{l}0.032^{* * *} \\
(0.000)\end{array}$ \\
\hline Leverage & $\begin{array}{l}0.041^{\star * *} \\
(0.000)\end{array}$ \\
\hline Revgrowth & $\begin{array}{l}0.008^{* * *} \\
(0.000)\end{array}$ \\
\hline Year & control \\
\hline Industry & control \\
\hline $\mathrm{N}$ & 12755 \\
\hline $\begin{array}{l}\text { Cox and Snell } \mathrm{R}^{2} \\
-2 \log \text { likehood }\end{array}$ & \\
\hline Adj. $\mathrm{R}^{2}$ & 0.039 \\
\hline F Value & 21.913 \\
\hline
\end{tabular}


Table 6. Results of retesting hypotheses with five market-oriented indicators.

\begin{tabular}{|c|c|c|c|c|c|}
\hline & GI & NEDI & PMI & EMI & MAI \\
\hline \multirow{2}{*}{ Constant } & $0.097^{\star * *}$ & $0.108^{\star * *}$ & $0.093^{* * *}$ & $0.114^{* * *}$ & $0.112^{* * *}$ \\
\hline & $(0.000)$ & $(0.000)$ & $(0.000)$ & $(0.000)$ & $(0.000)$ \\
\hline \multirow{2}{*}{ ICQ } & $0.012^{* *}$ & $0.011^{* *}$ & $0.030^{* * *}$ & -0.006 & -0.001 \\
\hline & $(0.030)$ & $(0.044)$ & $(0.001)$ & $(0.156)$ & $(0.667)$ \\
\hline \multirow{2}{*}{$\mathrm{RMI}_{\mathrm{n}}$} & $0.003^{* * *}$ & $0.001^{* *}$ & $0.003^{* * *}$ & $0.001^{*}$ & $0.001^{\star * *}$ \\
\hline & $(0.000)$ & $(0.023)$ & $(0.002)$ & $(0.093)$ & $(0.007)$ \\
\hline \multirow{2}{*}{$\mathrm{ICQ} \times \mathrm{RMI}_{\mathrm{n}}$} & $-0.003^{* * *}$ & $-0.002^{* * *}$ & $-0.004^{* * *}$ & 0.000 & $-0.001^{*}$ \\
\hline & $(0.001)$ & $(0.002)$ & $(0.000)$ & $(0.893)$ & $(0.082)$ \\
\hline \multirow{2}{*}{ State } & $-0.005^{\star * *}$ & $-0.005^{\star * *}$ & $-0.005^{\star * *}$ & $-0.005^{\star * *}$ & $-0.005^{\star * *}$ \\
\hline & $(0.000)$ & $(0.000)$ & $(0.000)$ & $(0.000)$ & $(0.001)$ \\
\hline \multirow{2}{*}{ Lnasset } & $-0.005^{\star * \star}$ & $-0.005^{\star * \star}$ & $-0.005^{\star * *}$ & $-0.005^{\star * \star}$ & $-0.005^{\star * \star}$ \\
\hline & $(0.000)$ & $(0.000)$ & $(0.000)$ & $(0.000)$ & $(0.000)$ \\
\hline \multirow{2}{*}{ Roe } & $0.033^{* * *}$ & $0.033^{* * *}$ & $0.033^{* * *}$ & $0.033^{\star * *}$ & $0.032^{* * *}$ \\
\hline & $(0.000)$ & $(0.000)$ & $(0.000)$ & $(0.000)$ & $(0.000)$ \\
\hline \multirow{2}{*}{ Leverage } & $0.040^{* * *}$ & $0.040^{* * *}$ & $0.040^{\star * *}$ & $0.041^{\star * *}$ & $0.041^{* * *}$ \\
\hline & $(0.000)$ & $(0.000)$ & $(0.000)$ & $(0.000)$ & $(0.000)$ \\
\hline \multirow{2}{*}{ Revgrowth } & $0.008^{\star * *}$ & $0.007^{* * *}$ & $0.007^{\star * *}$ & $0.008^{\star * *}$ & $0.008^{* * *}$ \\
\hline & $(0.000)$ & $(0.001)$ & $(0.001)$ & $(0.000)$ & $(0.000)$ \\
\hline \multicolumn{6}{|l|}{ Year } \\
\hline \multicolumn{6}{|l|}{ Industry } \\
\hline $\mathrm{N}$ & 12755 & 12755 & 12755 & 12755 & 12755 \\
\hline \multicolumn{6}{|l|}{ Cox and Snell $\mathrm{R}^{2}$} \\
\hline \multicolumn{6}{|l|}{$-2 \log$ likehood } \\
\hline Adj. $R^{2}$ & 0.040 & 0.039 & 0.040 & 0.039 & 0.039 \\
\hline F Value & 22.079 & 21.809 & 21.990 & 21.924 & 21.763 \\
\hline
\end{tabular}

1) The relationship between the government and the market, the development of the non-state-owned economy, and the degree of development of the product market can each affect the relationship between the quality of internal control and the quick money. When the degree of marketization of these three aspects is low, high-quality internal control promotes quick money; when the degree of marketization is high, the higher the degree of marketization, the more internal control can suppress the quick money;

2) The degree of development of the factor market does not affect the relationship between the quality of internal control and the quick money;

3) The development of market intermediaries and the legal environment of the market affect the relationship between the quality of internal control and the earning of fast money. When the degree of marketization is low, high-quality 
internal control cannot significantly inhibit the making of fast money; when the degree of marketization is high, the higher the degree of marketization, the more internal control can suppress the rapid money.

It can be seen that the relationship between the government and the market, the development of the non-state-owned economy, the development of the product market, the development of the market intermediary organization and the legal environment of the market respectively affect the relationship between the quality of internal control and the quick money. And the results of the impact are consistent with the results of the five aspects.

\section{Conclusions}

This paper takes the 2007-2016 Shanghai-Shenzhen A-share main board listed company as a research sample, and examines the difference in the impact of internal control quality on the quick money in different regions. The study found:

1) The suppression of fast money by high-quality internal control is affected by the degree of marketization in the region. If the Enterprise is in a region with low marketization, its internal control quality is not related to making quick money. On the contrary, the internal control of Enterprises with high degree of marketization has played a good inhibitory role.

2) In different aspects of the regional market environment, the relationship between the government and the market, the development of the non-state economy, the development level of the product market, the development of the market intermediary organization and the legal environment of the market will affect the internal control quality of the Enterprise's suppression on making quick money, and the results of the impact are consistent with the results of the five aspects. The degree of development of the factor market does not affect.

\section{Conflicts of Interest}

The author declares no conflicts of interest regarding the publication of this paper.

\section{References}

[1] Li, X.M. (2012) Analysis on the Institutional of Chinese Entrepreneurs Who Are Unmindful of Their Proper Work. East China Economic Management, No. 6, 87-90.

[2] Dai, W.Q., Liu, Y. and Liao, M.Q. (2016) The Branding Effect: Who Is a Private Enterprise Who Is Not Doing Business? Management World, No. 5, 99-115.

[3] Wang, H.J., Li, M.M. and Tang, T.J. (2016) The Driving Factors of Cross-Industry Arbitrage of Entity Enterprises and Their Impact on Innovation. Chinese Industrial Economy, No. 11, 73-89.

[4] Fan, G., Wang, X.L. and Zhu, H.P. (2011) China Marketization Index: Report on the Relative Progress of Marketization in Various Regions in 2011. Economic Science Press, Beijing.

[5] Wang, X.L., Fan, G. and Yu, J.W. (2017) China's Provincial Marketization Index 
Report 2016. Social Science Literature Publishing House, Beijing.

[6] Li, S.Y. and Miao, J. (2018) Regional Corruption, Marketization and Overcapacity. Contemporary Economic Science, No. 2, 94-113.

[7] Zhang, X.Y., Xin, B.H. and Du, L.Q. (2018) A Marketization Eliminate Discrimination? Evidence from "Height Premium". Financial Research, No. 5, 140-152.

[8] Wang, Z.S. and Wang, X.Y. (2018) Balance of Stocks, Degree of Marketization and Maturity of Corporate Debt. Financial Problem Research, No. 3, 62-69.

[9] Tian, W. (2007) Enterprise Decision Model Considering Local Government Factors-Interpretation of China's Macroeconomic Phenomena Based on Enterprise Micro Perspective. Management World, No. 5, 16-23.

[10] Jiang, W. (2007) Marketization, Industry Competition and Managerial Salary Growth. Nankai Management Review, No. 5, 58-67.

[11] Fang, H.X. and Jin, Y.N. (2013) Perceived Internal Control Quality: Measurement Methods and Preliminary Tests. Financial Problem Research, No. 10, 18-25.

[12] Li, C. (2015) Regional Marketization Process and Cash Dividends Cater to Behavior. Finance and Trade Research, No. 2, 139-147. 